\title{
Exploring the Issues and Challenges in Malaysian Cosmetic Halal: A Theoretical Framework
}

\author{
Alina Shamsuddin ${ }^{1}$ and Farahwahida Mohd Yusof ${ }^{2}$ \\ ${ }^{1}$ Faculty of Technology Management and Business, Universiti Tun Hussein Onn Malaysia, 86400 \\ Parit Raja, Johor, Malaysia \\ ${ }^{2}$ Centre of Research for Fiqh Science and Technology (CFiRST), Ibnu Sina Institute for Scientific \\ and Industrial Research (ISI-SIR), Universiti Teknologi Malaysia, 81310 Skudai, Johor, Malaysia \\ Correspondence should be addressed to Alina Shamsuddin; alina@uthm.edu.my
}

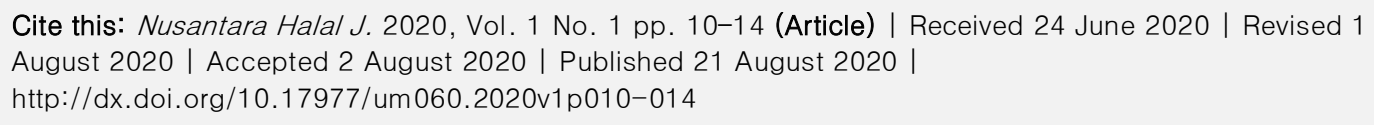

\begin{abstract}
Halal Industry in Malaysia has been prevalent in the manufacturing sectors and has earned the government's concern in supporting its development. The Halal Industry sector has been considered as one of the leading contributors to Malaysian economy development in the future. This is due to the fact that the market of Halal products is reasonable to Muslims and has received pervasive attention from non-Muslims consumers who consider Halal commercialism. Halal industry has been categorized into seven sectors, which are cuisine, goods, financial, pharmaceutical, cosmetics, logistics, and tourism businesses. However, much attention has been given to issues and challenges to food services. Consequently, this study aims to address the influencing features of adopting Halal practices among Halalan Toyyiban Risk Management Plan (HTRMP) practices in the cosmetic industry. Besides, it adopts the Technology Acceptance Model (TAM) model to describe the influencing of adopting factors in cosmetic sectors in a conceptual framework.
\end{abstract}

Keywords: halal industry, halalan toyyiban risk management plan (HTRMP), cosmetic halal, technology acceptance model (TAM).

\section{Introduction}

Muslims population in the world is predicted to reach 2.2. billion in 2030 [1]. As a result, Halal Industry has gained much attention from Muslim world due to the comprehensiveness of halal procedures in terms of hygiene, cleanliness, health, and the production process for the product they either consume, use and purchase by consumers [1]. All products and services produced 
with halal preparations are willingly tolerable by either Muslim or consumers from other religions [2]. Moreover, Halal standards encourage practitioners to adopt them because of their future benefits [3]. Another main contribution of Halal Industry is in economic development [4]. Much has been researched pertaining to Halal issues, but the main concern is on the HalalanToyyiban aspects [5]. Moreover, international institutions have started to show interest in Halal standards [6], which serves as a means to ensure the Halal and toyyiban logistic networks, from procuring until it reaches the consumers.

Halal Industry has been categorized into seven sectors, namely food, goods, financial, pharmaceutical, cosmetics, logistics, and tourism businesses. There has been abundance of research on Halal issues and challenges. For instance, on the influencing factors for Halal practices [7], new motivation for SMEs to become Halalprenuers [8], applying Theory of Consumption Value (TCV) in intention to use Halal products, and [9] issues on food implementation [10]. However, much attention has been given to issues and challenges to food services and Halal supply chain. Research on cosmetic sector in Halal Industry has found to be limited. Thus, this paper explores the issues and challenges in cosmetic sector in Malaysia in adopting the HTRMP practices and proposes a conceptual framework using the Technological, Organization and Environment (TOE) model.

\section{Literature Review}

\section{Fiqh Platforms}

The meaning of Halal is appropriate, acceptable, approved, and/or permissible. It does not concern with the cuisine products (the way most people assume or think), yet it deals with Muslims life aspects (male or female) [11]. Meanwhile, the term tayyib in the holy Qur'an is always correlated with the approval of a specific endeavor or associated closely with the innocence of someone in performing something.

Allah the Almighty has said: "O you Messengers! Eat of the good things and act righteously" (23:51-53).

Every Muslims must consume Halal (lawful) and qualified things as needed. These two aspects will guarantee both physical health and alertness, as well as become a driving factor in helping to accelerate the quality of one's taqwa (God-fearing) and syukur (Gratefulness) toward Allah SWT. It has been distinctly declared in the Holy Qur'an, sentence 172 of Surah Al-Baqarah.

And Allah the Almighty also declared: "O you who believe! Eat of the good things that We have provided you with" (2:167- 172).

According to Malaysian standards MS1500:2009, Halal is Sharia-based aspects that exclude punishment in the practices [12]. Furthermore, it is explained in the MS2400:2010 (Part 1 item 2.19) that Halal means allowing any conducts to be done, which accepts the Islamic consensus for goodness [13]. 
In summary, Halal is not pernicious, not intoxicating, and non-hazardous to health and follow according to al-quran and as-sunnah that deals with food and beverages, as well as also other sectors such as banking, finance, travel, economy, and so forth.

\section{HTRMP in Halal concepts}

Halalan-toyyiban risk management plan (HTRMP) involves many handling points processes. It indicates that the management point can be one of the important commanding points. That way, products' Halal position may be influenced by the not fully understood Halal integrity concept by the parties involved in the supply chain, particularly those working in the operational management aspects. The Department of Standards Malaysia in MS2400-2:2010 echoes some principles of HTRMP that comprise of seven steps [13], which are: 1. Identification of HalalanToyyiban potential contaminant and/or precursor, 2. Determination of control measures, 3. Determination of Halalan-Toyyiban Control Point, 4. Determination of monitoring system for Halalan-Toyyiban Control Point, 5. Determination of corrective actions for Halalan-Toyyiban Control Point, 6. Determination of the verification process and documentation system, 7. Management of records [13]. Consequently, Halal aspects are linked to all Shariah compliance features and can be discussed with additional associated measures, as listed in Table 1 [5].

Table 1. List of Halal standards regulations established by Department of Standards Malaysia

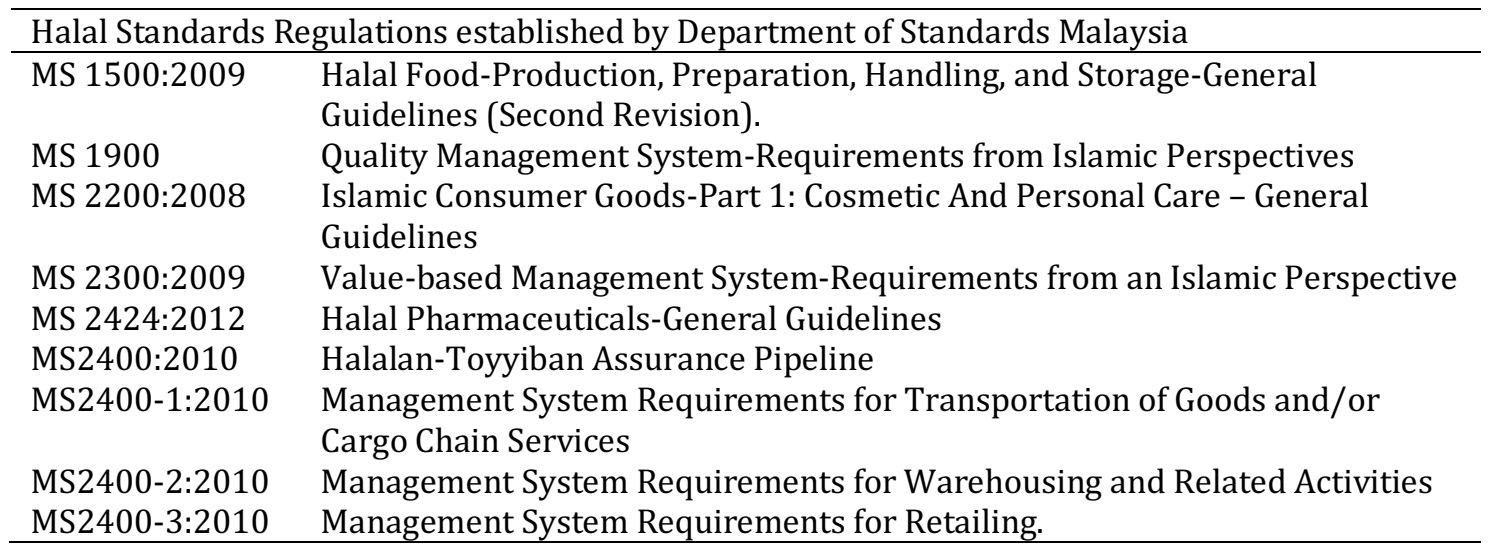

\section{Overview of Halal Cosmetics}

The pharmaceuticals and cosmetic Halal products have gained responsiveness and growing demand from around 2.4 billion worldwide Muslim consumers [14]. Moreover, based on Allied Market Research (AMR), the market of Halal cosmetics products has widened its product base to tap into the cosmetics market prominently. As a consequence, it drives the increasing request for worldwide Halal cosmetic products, primarily in regions dominated by Muslim population, such as Malaysia, Indonesia, Saudi Arabia, and UAE. Sugibayashi (2019) stated that Halal cosmetics must not incorporate components attained from pig, decaying flesh, blood, portions of human body, predatory animals, reptiles, and insects [14]. As a result, the Halal logo in halal cosmetics should be acknowledged as a sign of hygiene, security, cleanliness, and quality. Another interesting study in Malaysia on the adoption of Halal cosmetics among Malaysian consumers indicates that awareness and understanding, perceived attributes of innovation, and social encouragement had a substantial positive impact whereas, financial cost has an essential negative impact on the adoption [15]. In another study, social influence and consumer 
innovativeness have been found as the influencing factors of young Muslims to adopt Halal cosmetic products, and religiosity have been found as the moderator of the adoption [16]. Moreover, the adoption factors of Halal standard influenced by technology, organization, and environmental factors among Malaysia are being used for applying in HTRMP [17].

\section{Conceptual Framework}

Based on the discussions, it is apparent that previous research focuses more on Halal supply chain management and food sector. Whilst, less attention has been given to toyyiban aspect in the cosmetic sector in Halal Industry. Moreover, the technology adoption model has been the essential methods in previous research to identify the influencing factors of Halal products. Factors like awareness and understanding, perceived attributes of innovation, and social influence consumer innovativeness and religiosity have been found to be the influencing factors of Halal products. In summary, the researchers concluded that; (i) Halal Industry has gained much attention from previous researchers and practitioners, (ii) the importance of Halal Industry as a new market force and brand identifier, (iii) Halalan-toyyiban risk management plan practices in Halal industry is gaining more attention as it is more challenging to maintain the Halalness rather than to obtain the Halal certificates. This research's theoretical framework is the Technology Acceptance Model (TAM), reasoned action theory adaptation primarily tailored for modeling user approval of information systems [18]. The two primary concepts of TAM are the perceived practicality (usefulness) and perceived ease of use. TAM suggests that authentic system use is established by behavioral intention to use. In turn, intention to use is influenced by attitude, along with perceived practicality. Besides, behavioral intention is being shaped by perceived practicality and perceived ease of use. In addition, perceived ease of use also affects perceived practicality. The peripheral variables influence behavioral intention incidentally through perceived practicality and perceived ease of use. Hence, TAM framework is adopted to elaborate on the influencing features of HTRMP practices, as indicated in Fig 1.

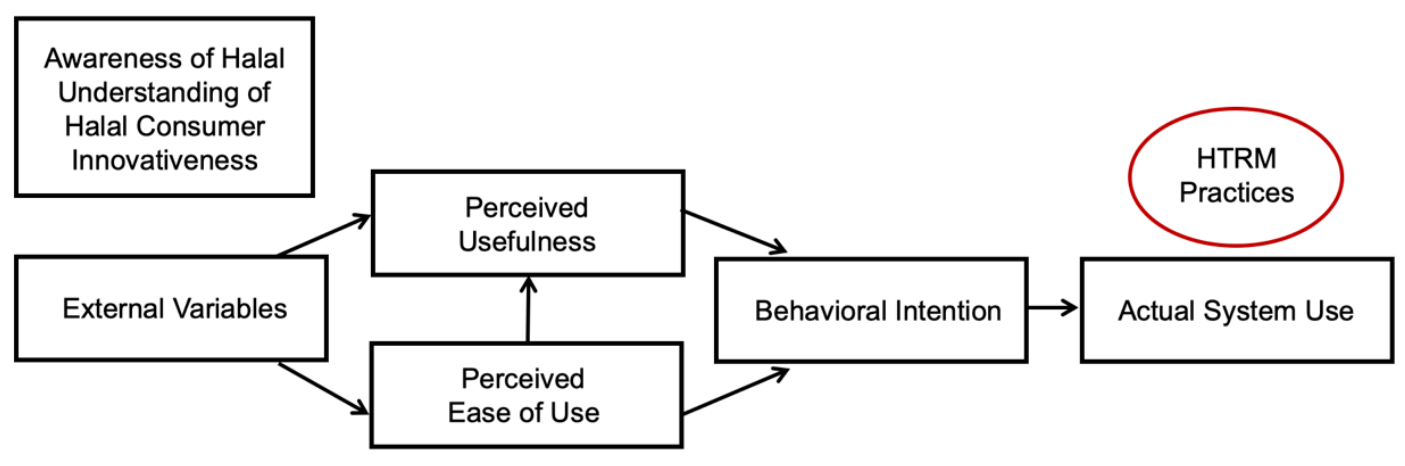

Figure 1. Theoretical framework of influencing factors of Halalan-Toyyiban Risk Management (HTRMP) practices

\section{Acknowledgments}

The authors would like to declare their gratitude to Universiti Teknologi Malaysia (UTM) and the Research Management Centre (RMC). This study is financed by the RUG UTM entitled Design and Development of Virtual Learning Environment for Halal Human Capital Development. Ref No: PY/2017/01749. 


\section{References}

[1] A. Hamid, M. Said, and E. Meiria, "Potency and prospect of halal market in global industry: an empirical analysis of Indonesia and United Kingdom," Bus. Manag. Stud., vol. 5, no. 2, pp. 54 63, 2019.

[2] A. R. Ambali and A. N. Bakar, "People's awareness on halal foods and products: Potential issues for policy-makers," Procedia-Social Behav. Sci., vol. 121, no. 19, pp. 3-25, 2014.

[3] F. R. Azmi, H. Musa, H. Sihombing, and F. S. Fen, "Adoption factors of halal standards: The Malaysian perspectives," in Proceedings of the 3rd International Halal Conference (INHAC 2016), 2018, pp. 315-329.

[4] N. H. N. Azman and T. A. Masron, "Halal development and food exports: evidence from Malaysia and MEACs," Pros. Perkem VII, vol. 1, no. 2012, pp. 318-324, 2012.

[5] H. Yahya, Z. Samicho, and A. F. M. N. Azmi, "A review on application of halalan-toyyiban risk management plan (HTRMP) and frozen food chain during warehousing activities for maintaining halal, safety, and quality," J. Appl. Environ. Biol. Sci., vol. 6, no. 11, pp. 12-96, 2016.

[6] M. N. Demirci, J. M. Soon, and C. A. Wallace, "Positioning food safety in Halal assurance," Food Control, vol. 70, no. 2016, pp. 257-270, 2016.

[7] A. H. Ngah, Y. Zainuddin, and R. Thurasamy, Contributing factors of Halal warehouse adoption. London: CRC Press, 2014.

[8] M. Soltanian, S. Zailani, M. Iranmanesh, and A. A. Aziz, "Motivations of SME entrepreneurs to become halalpreneurs,” J. Sci. Technol. Policy Manag., vol. 7, no. 2, pp. 173-189, 2016.

[9] B. L. Yeo, R. H. N. Mohamed, and M. Muda, "A study of Malaysian customers purchase motivation of halal cosmetics retail products: Examining theory of consumption value and customer satisfaction," Procedia Econ. Financ., vol. 37, no. 2016, pp. 176-182, 2016.

[10] M. A. A. Majid, I. H. Z. Abidin, H. A. M. A. Majid, and C. T. Chik, "Issues of halal food implementation in Malaysia," J. Appl. Environ. Biol. Sci., vol. 5, no. 6, pp. 50-56, 2015.

[11] M. I. Khan and A. Haleem, "Understanding halal and halal certification \& accreditation system: a brief review,” Saudi J. Bus. Manag. Stud., vol. 1, no. 1, pp. 32-42, 2016.

[12] "Halal food-production, preparation, handling and storage-general guidelines (second revision)," Standard Malaysia, Department of Standards, Selangor Darul Ehsan, Malaysia, MS1500. Darul Ehsan, Selangor, 2009.

[13] F. K. K. P. Halalan-Toyyiban, "Halalan toyyiban assurance pipeline-management system requirements for transportation of goods and cargo chain services," SM (SM), YES (YES), and HIDC (HDC), Editors. 2010.

[14] K. Sugibayashi et al., "Halal cosmetics: A review on ingredients, production, and testing methods," Cosmetics, vol. 6, no. 3, p. 37, 2019.

[16] Q. Ali, A. Salman, H. Yaacob, and S. Parveen, "Financial cost and social influence: factors affecting the adoption of halal cosmetics in malaysia," Acad. Entrep. J., vol. 25, no. 2, pp. 1-17, 2019.

[17] N. Saleh, I. Ibrahim, and F. Abd Rahman, "Determine the factors of influence the technological, organizational, environmental, halal awareness towards halalan-toyyiban risk management plan (HTRMP)," Transportation (Amst)., vol. 2, no. 09, pp. 109-114, 2019.

[18] F. D. Davis, "Perceived usefulness, perceived ease of use, and user acceptance of information technology," MIS Q., vol. 13, no. 3, pp. 319-340, 1989.

\section{Corresponding author biography}

Alina Shamsuddin obtained her Ph.D. from the University of Strathclyde in 2007. Currently, she is an Associate Professor at the Faculty of Technology Management and Business, Universiti Tun Hussein Onn Malaysia (UTHM). Her current research interest includes outcome-based education (OBE), technological capability- innovation, and institution higher learning leadership. 